pag

Business School

WORKING PAPER SERIES

Working Paper

$2015-622$
Financial Development, Environmental Quality, Trade and Economic Growth : What Causes What in MENA Countries

Anis Omri

Saida Daly

Anissa Chaibi

Christophe Rault

http://www.ipag.fr/fr/accueil/la-recherche/publications-WP.html

IPAG Business School

184, Boulevard Saint-Germain

75006 Paris

France 


\title{
Financial Development, Environmental Quality, Trade and Economic Growth : What Causes What in MENA Countries ${ }^{1}$
}

\author{
Anis Omri* \\ Faculty of Economics and Management, University of Sfax, Tunisia \\ E-mail: omrianis.fsegs@gmail.com \\ Corresponding author. Tel.: +21697914294. \\ Saida Daly \\ Faculty of Economics and Management, University of Sfax, Tunisia \\ E-mail: dalysaida@gmail.com \\ Anissa Chaibi \\ IPAG Lab, IPAG Business School, Paris, France \\ E-mail: anissa.chaibi@ipag.fr \\ Christophe Rault \\ University of Orleans (CNRS, LEO, UMR 7322), Orleans, France \\ E-mail: chrault@hotmail.com
}

\begin{abstract}
This paper examines the relationship between financial development, $\mathrm{CO}_{2}$ emissions, trade and economic growth using simultaneous-equation panel data models for a panel of 12 MENA countries over the period 1990-2011. Our results indicate that there is evidence of bidirectional causality between CO2 emissions and economic growth. Economic growth and trade openness are interrelated i.e. bidirectional causality. Feedback hypothesis is validated between trade openness and financial development. Neutrality hypothesis is identified between $\mathrm{CO}_{2}$ emissions and financial development. Unidirectional causality running from financial development to economic growth and from trade openness to $\mathrm{CO}_{2}$ emissions is identified. Our empirical results also verified the existence of environmental Kuznets curve. These empirical insights are of particular interest to policymakers as they help build sound economic policies to sustain economic development and to improve the environmental quality.
\end{abstract}

Keywords: Financial development, $\mathrm{CO}_{2}$ emissions, Trade, Economic growth, Simultaneous-equation models.

\footnotetext{
${ }^{1}$ We are grateful to two anonymous referees for helpful comments and suggestions on an earlier version of the paper.
} 


\section{Introduction}

The relationship between energy consumption and economic growth has been the subject of considerable academic research over the past few decades (Omri, 2013). Various studies have focused on different countries, time periods, modeling techniques and different proxy variables which have been used for energy consumption and economic growth nexus (e.g. Stern, 1993, Wolde-Rufael, 2005; Yuan et al., 2007; Apergis and Payne, 2009, Ghosh, 2010 ; Baranzini et al., 2013), but in general the empirical results are mixed and have not reached on unique consensus (Chen et al., 2007; Omri, 2014). From the existing studies, one can observe that the Granger causality test has been widely carried out to study the direction of causality between the two variables (Farhani et al., 2014). However, it is clear that the litearure on energy consumption-growth nexus produced inconclusive results and theire is a consensus neither on the existence nor on the direction of causality (Farhani et al., 2014). A major reason for the absence of consensus is that Granger causality test in a bivariate framework is likely to be biased due to the omission of relevant variables affecting energy consumption and economic growth nexus (Stern, 1993).

This problem has led some of wich recent Granger causality basezd-studies investigating the causal links between energy consumption and economic growth to incorporate capital and labor in the multivariate models (e.g. Apergis and Payne, 2010a; Bartleet and Gounder, 2010; Zhixin and Xin, 2011; Sadorsky, 2012; Shahbaz and Lean, 2012; Mallick and Mahalik, 2014). Recently, some other studies have incorporated trade openness in the production function in order to investigate the relationship between economic groxth, capital, labor and trade (e.g. Narayan and Smyth, 2009 ; Lean and Smyth, 2010a ; and Sadorsky, 2012). In addition to energy and trade, some of the recent studies such as Islam et al. (2013) and Ozturk and Acaravci (2013) have included financial financial development in the production function. Financial development, which refers to a country's decision to allow and promote activities like increased foreign direct investment (FDI), increases in banking activity, and increases in stock market activity, presents one possible avenue for which economic growth can be increased (Sadorsky, 2010).

Several existing studies in energy economics have argued that energy consumption and economic growth may generate considerable pressure on the environment quality (e.g. Apergis and Payne, 2010b; Arouri et al., 2012; Shahbaz et al., 2013c; Tiwari et al., 2013; Omri et al., 2014). As often mentioned in the environmental Kuznets curve (EKC) literature, 
as output increases, carbon dioxide emissions increase as well until some threshold level of output was reached after which these emissions begin to decline. An assessment of the existing literature reveals that at the time of writing this work, papers by Ozturk and Acaravci (2013) in Turkey, Shahbaz et al. (2013c) in South Africa, appear to be the only published papers specifically investigating the relationship between economic growth, energy, trade, financial development, and $\mathrm{CO}_{2}$ emissions. The main contribution of these studies is to allow examining the causal relationships between economic growth, energy consumption, trade, financial development, and $\mathrm{CO}_{2}$ emissions in an integrated framework and with time series econometric model. Given that these five variables are strongly interrelated, the use of a naive bivariate or trivariate framework may be subject to the omitted variable bias (Ang, 2009; Jayanthakumaran et al., 2012).

The objective of this study is to use production function approach where GDP depends on $\mathrm{CO}_{2}$ emissions, capital and others inputs such as financial development and trade. The extended Cobb-Douglas production framework helps us to explore the causal relationships among the variables: economic growth, capital, $\mathrm{CO}_{2}$ emissions, financial development and trade. The variables are chosen to capture the particular characteristics of MENA countries. Our study thus contributes to the existing literature by given the first integrated approach to examine the four-way linkages between economic growth, $\mathrm{CO}_{2}$ emissions, financial development and trade in the Middle East and North Africa (MENA) region by using the simultaneous-equation models with both panel and time series econometric techniques for 12 MENA countries over the period 1990-2012. Specifically, this study uses four structural equation models, which allows one to simultaneously examine the impact of (i) $\mathrm{CO}_{2}$ emissions, financial development and trade on economic growth, (ii) economic growth, financial development and trade on $\mathrm{CO}_{2}$ emissions, (iii) economic growth, $\mathrm{CO}_{2}$ emissions and trade on financial development, and (iv) economic growth, $\mathrm{CO}_{2}$ emissions and financial development on trade. Therefore, more useful and reliable information can be provided to the policymakers to formulate effective policies to promote long-term economic growth for the MENA region. This region was chosen as the focus of this study because empirical analysis of countries in this region is relatively scarce. In addition, the characteristics of the countries in the MENA region are very suitable to the case of the present study, for example, this region has some of the largest energy reserves in the world. Yet, while the region is trying to industrialize and modernize its economies, there are the challenges of the carbon emissions. Moreover, energy consumption is the most significant source of pollution and, in terms of 
particulate matter concentrations; MENA represents the second most polluted region in the world - after South Asia - and the highest $\mathrm{CO}_{2}$ producer per dollar of output.

The algorithm of the article is as such: section 2 briefly reviews the related literature, followed by section 3 that is going to outline the econometric modeling approach and describe the data used, section 4 depicts the empirical findings and the final section, being section 5 , holds the concluding annotations and offers some policy implications.

\section{Literature review}

Several existing works on the nexus among economic growth and $\mathrm{CO}_{2}$ emissions, financial development and trade are carried on a piecemeal basis without a comprehensive model in mind and thus ignore the potential interaction among the series. Thus this paper reviews the literature under three subsections, e.g. (a) economic growth and $\mathrm{CO}_{2}$ emissions; (b) financial development and $\mathrm{CO}_{2}$ emissions (c) trade openness and financial development. We discuss them in turn below.

\subsection{Economic growth and $\mathrm{CO}_{2}$ emissions}

The relationship between economic growth and $\mathrm{CO}_{2}$ emissions has been intensively analyzed empirically over the past two decades. This nexus is closely related to testing the validity of the so-called environmental Kuznets curve (EKC) hypothesis. Several existing studies on this nexus have argued that the level of environmental degradation and economic growth follows the inverted U-shaped relationship. This U-shaped relationship is known as the Environmental Kuznets Curve (EKC) in the literature. This relationship has been examined since the 1990s after Grossman and Krueger (1991) and Selden and Song (1994) provided empirical evidence that the economic growth leads to a gradual degradation of the environment in its initial stages and, after a certain level of growth, it leads to an improvement in the environmental conditions.

Following this seminal study, a number of works such as inter alia, Stern et al. (1996), Ekins (1997), Heil and Selden (1999), Managi and Jena (2008), Fodha and Zaghdoud (2010), Jaunky (2010), Ozturk and Acaravci (2010), and Saboori et al. (2012) tested the EKC hypothesis. However, these studies show a range of conflicting results.

Where as some research found a linear relationship between $\mathrm{CO}_{2}$ emissions and economic growth (e.g. Shafik, 1994; Azomahou et al., 2006) others reported an inverted U-shaped relationship (e.g. Lean and Smyth, 2010b; Saboori et al., 2012) or even an N-shaped 
relationship (e.g. Shafik, 1994 ; Friedl and Getzner, 2003) others showed no relationship (e.g. Richmond and Kaufmann, 2006). One limitation of this branch of the literature is that they are likely to suffer from the omitted variables bias problem for the simple reason that their empirical model is only a bivariate one.

For that reason, some studies included other potential determinants of $\mathrm{CO}_{2}$ emissions such as trade openness in order to test the pollution haven hypothesis by Halicioglu (2009), Nasir and Rehman(2011); urbanization by Zhang and Cheng (2009), Hossain (2011), and Sharma (2011); and financial development by Ozturk and Acaravci (2013). However, the multivariate studies also produce conflicting results on the existence of EKC. While Ang (2007) and Iwata et al. (2010) for France, Jalil and Mahmud (2009) for China, Nasir and Rehman (2011) for Pakistan, and Omri (2013) for 12 MENA countries succeed in finding an inverted-U shaped curve between economic growth and $\mathrm{CO}_{2}$ emissions, others could not (Halicioglu, 2009; Ozturk and Acaravci, 2010 all for turkey; Jaunky, 2010 for 36 high-income countries ; and Menyah and Wolde-Rufael, 2010 for South Africa).

\subsection{Financial development and $\mathrm{CO}_{2}$ emissions}

Financial infrastructure can enhance economic growth and lowers $\mathrm{CO}_{2}$ emissions (Tamazian et al., 2009). However, Sadorsky (2010) and Zhang (2011), who argue that financial development increases $\mathrm{CO}_{2}$ emissions. According to these studies, financial development leads to increase in $\mathrm{CO}_{2}$ emissions for the following ways: First, stock market development helps listed enterprises to lower financing costs, increase financing channels, disperse operating risk and optimize asset/liability structure, so as to buy new installations and invest in new projects and then increase energy consumption and carbon emissions. Second, financial development may attract foreign direct investment so as to boost economic growth and increase carbon emissions. Third, prosperous and efficient financial intermediation seems conducive to consumers' loan activities, which makes it easier for consumers to buy big ticket items like automobiles, houses, refrigerators, air conditioners, washing machines, etc. and then emit more carbon dioxide (Zhang, 2011).

Recent studies which examine the relationship between financial development on $\mathrm{CO}_{2}$ emissions are as follows: Tamazian and Bhaskara Rao (2010) argue that financial development in transition countries may exert evident influence on $\mathrm{CO}_{2}$ emissions. Jalil and Feridun (2011) examine the impact of financial development, economic growth and energy consumption on $\mathrm{CO}_{2}$ emissions in China. Their findings reveal a negative sign for the 
coefficient of financial development, suggesting that financial development in China has not taken place at the expense of $\mathrm{CO}_{2}$ emissions. More recently, Ozturk and Acaravci (2013) investigate the causal relationship between financial development, trade, economic growth, energy consumption, and carbone missions in Turkey. The results show that there is an evidence of a long-run causal relationship from per capita energy consumption, per capita real income, the square of per capita real income, openness and financial development to per capita carbon emissions. Shahbaz et al. (2013b) examine the causal links among economic growth, energy consumption, financial development, trade openness and $\mathrm{CO}_{2}$ emissions in Indonesia. They show that economic growth and energy consumption increase $\mathrm{CO}_{2}$ emissions, while financial development and trade openness compact it. The VECM causality analysis has shown the feedback hypothesis between energy consumption and $\mathrm{CO}_{2}$ emissions. Economic growth and $\mathrm{CO}_{2}$ emissions are also interrelated i.e. bidirectional causality. Financial development Granger causes $\mathrm{CO}_{2}$ emissions.

\subsection{Trade and financial development}

The relationship between international trade and financial development has been investigated in the recent years by various researchers. Yucel (2009) examined the causality relations between financial development, trade openness and economic growth in the Turkia. They showed that the Granger causality test results revealed the presence of bidirectional causal relationship between financial development, trade openness and growth indicating that economic policies aimed at financial development and trade openness have a statistically significant impact on economic growth.

More recently, Menyah et al. (2014) investigate the causal relationship between financial development, trade openness and economic growth for 21 African countries. The results indicate a unidirectional causality running from financial development to trade openness in the case of Burundi, Malawi, Niger, Senegal and Sudan. The opposite causality running from trade openness to financial development was supported only in Gabon. For the remaining sixteen countries, that is for more than three-quarters of the sample, therewas no causality running in any direction between financial development and trade openness implying that financial development and trade openness do not have predictive power on each other.

\section{Econometric issues}




\subsection{Models specifications}

To examine the four-way linkages between $\mathrm{CO}_{2}$ emissions, financial development, trade, and economic growth in MENA countries, we used a Cobb-Douglas production function whereby the gross domestic product (GDP) depends on capital and labor force. The income depends also on energy consumption, which is directly related to $\mathrm{CO}_{2}$ emissions (e.g. Stern, 2000, Ang, 2008; Sharma, 2010). Specifically, we use the following extended Cobb-Douglas production function:

$\mathrm{Y}=\mathrm{AK}^{\alpha} E^{\lambda} \mathrm{L}^{\beta} e^{u}$

where $Y$ is the real income, $\mathrm{E}, \mathrm{K}$ and $\mathrm{L}$ denote respectively, energy consumption, capital stock and labor force. The term A refers to technology and e the error term. $\alpha, \lambda$, and $\beta$ are the production elasticities with respect to domestic capital, energy consumption, and labor force, respectively. When Cobb-Douglas technology is restricted to $(\alpha+\lambda+\beta=1)$ we get constant returns to scale. Given the technology level at given point in time, there is a direct linear relationship between energy consumption and $\mathrm{CO}_{2}$ emissions (Pereira and Pereira, 2010) such as $\mathrm{E}=b \mathrm{C}$. Then, we have

$\mathrm{Y}=b^{\lambda} \mathrm{AK}^{\alpha} C^{\lambda} \mathrm{L}^{\beta} e^{u}$

In our model we allow technology to be endogenously determined by trade and financial development and within an augmentd Cobb-Douglas production function (Shahbaz and Lean, 2012). Financial development encourages the inflow of foreign direct investment and transfer of superior technology; it promotes economic growth via capital formation in making its efficient use. International trade helps technological advancements and its diffusion. Therefore, we have :

$$
A(t)=\theta \cdot F D(t)^{\alpha} T(t)^{\beta}
$$

where $\theta$ is time-invariant constant, FD and T denote respectively, finacial development and trade openness. Substituting Eq. (3) into Eq. (2):

$$
\mathrm{Y}(\mathrm{t})=\theta \cdot C(t)^{\lambda_{1}} \mathrm{FD}(\mathrm{t})^{\lambda_{2}} \mathrm{~T}(\mathrm{t})^{\lambda_{3}} \mathrm{~K}(\mathrm{t})^{\alpha} \mathrm{L}(\mathrm{t})^{1-\alpha}
$$


We then divide both sides of Eq. (4) by L to get variables in per capita terms; but leave the impact of labor constant. By taking log, the linearized production function can be given as follows :

$$
\ln Y_{t}=\alpha_{1}+\alpha_{2} \ln C_{t}+\alpha_{3} \ln F D_{t}+\alpha_{4} \ln T_{t}+\alpha_{5} \ln K_{t}+\varepsilon_{t}
$$

Since our study is a panel data study, Eq. (5) can be written in panel data form as follows:

$$
\ln Y_{i t}=\alpha_{1}+\alpha_{2 i} \ln C_{i t}+\alpha_{3 i} \ln F D_{i t}+\alpha_{4 i} \ln T_{i t}+\alpha_{5 i} \ln K_{i t}+\varepsilon_{i t}
$$

Where the subscript $\mathrm{i}=1, \ldots . ., \mathrm{N}$ denotes the country (in our study, we have 12 countries) and $\mathrm{t}=1, \ldots \ldots, \mathrm{T}$ denotes the time period (our time frame is $1990-2011$ ), $\ln Y$ is real output, $\ln C$ is the indicator of $\mathrm{CO}_{2}$ emissions, $\ln F D$ is financial development measured as domestic credit to private sector as share of GDP, $\ln T$ is trade openness, and $\ln K$ is capital stock., and $\varepsilon$ is the error term.

We then use the production function in Eq. (6) to derive the empirical models to simultaneously examine the interactions between per capita GDP, per capita $\mathrm{CO}_{2}$ emissions, financial development, and trade. These simultaneous-equation models are also constructed on the basis of the theoretical and empirical insights from the existing literature. While estimating the causal links between $\mathrm{CO}_{2}$ emissions-financial development-trade-growth, capital (K), Square of GDP $\left(\mathrm{Y}^{2}\right)$, energy consumption (E), urbanization (UR), inflation (IF), and foreing direct investment (FDI) are inculded as instrumental variables.

The four-way linkages between growth-environment-trade-financial development are empirically examined by making use of the following four equations:

$$
\begin{aligned}
& \ln Y_{i t}=\alpha_{1}+\alpha_{2 i} \ln C_{i t}+\alpha_{3 i} \ln F D_{i t}+\alpha_{4 i} \ln T_{i t}+\alpha_{5 i} \ln K_{i t}+\varepsilon_{i t} \\
& \ln C_{i t}=\alpha_{1}+\alpha_{2 i} \ln Y_{i t}+\alpha_{3 i} \ln F D_{i t}+\alpha_{4 i} \ln T_{i t}+\alpha_{5 i} \ln Y_{i t}^{2}+\alpha_{6 i} \ln E_{i t}+\alpha_{7 i} \ln U R_{i t}+\varepsilon_{i t} \\
& \ln F D_{i t}=\alpha_{1}+\alpha_{2 i} \ln Y_{i t}+\alpha_{3 i} \ln C_{i t}+\alpha_{4 i} \ln T_{i t}+\alpha_{5 i} \ln I F_{i t}+\varepsilon_{i t} \\
& \ln T_{i t}=\alpha_{1}+\alpha_{2 i} \ln Y_{i t}+\alpha_{3 i} \ln C_{i t}+\alpha_{4 i} F D_{i t}+\alpha_{5 i} F D I_{i t}+\varepsilon_{i t}
\end{aligned}
$$

In the above equations, the subscript $i=1, \ldots, N$ denotes the country and $t=1, \ldots, T$ denotes the time period. Eq. (7) states that $\mathrm{CO}_{2}$ emissions (C), the level financial development (FD), trade openness (T) and capital stock (K) are the driving forces of economic growth (Y) (e.g. Ang, 2008; Menyah and Wolde-Rufael, 2010; Anwar and Sun, 2011). Eq. (8) postulates 
that $\mathrm{CO}_{2}$ emissions $(\mathrm{C})$ can be influenced by economic growth $(\mathrm{Y})$, the level of financial develoment (FD), trade openness (T), Square of GDP ( $\mathrm{Y}^{2)}$, energy consumption (E), and urbanization (URB) (e.g. Lotfalipour et al., 2010; Hossain, 2011; Sharma, 2011 ; Saboori et al., 2012 ; Lee, 2013). Eq. (9) states that the level of financial development (FD) can be affected by economic growth (Y), $\mathrm{CO}_{2}$ emissions (C), trade openness (T), and consumer price index (e.g. Ahlin and Pang, 2008 ; Ozturk and Acaravci, 2013). With respect to Eq. (10), the factors including economic growth (Y), $\mathrm{CO}_{2}$ emissions (C), financial development (FD), and foreign direct investment net inflows (FDI) can potentially affect trade (e.g. Ozturk and Acaravci, 2013 ; Belloumi, 2014).

Eq. (7) to (10) were estimated simultaneously by means of the generalized method of moments (GMM). The GMM is the estimation method most commonly used in models with panel data and in the multiple-way linkages between certain variables. This method uses a set of instrumental variables to solve the endogeneity problem.

It iswell-known that the GMM method provides consistent and efficient estimates in the presence of arbitrary heteroskedasticity. Moreover, most of the diagnostic tests discussed in this study can be cast in a GMM framework. Hansen's test was used to test the overidentifying restrictions in order to provide some evidence of the instruments' validity. The instruments' validity is tested using Hansen test which cannot reject the null hypothesis of overidentifying restrictions. That is, the null hypothesis that the instruments are appropriate cannot be rejected. The Durbin-Wu-Hausman test was used to test the endogeneity. The null hypothesis was rejected, suggesting that the ordinary least squares estimates might be biased and inconsistent and hence the OLS was not an appropriate estimation technique.

The GMM estimation with panel data proves advantageous to the OLS approach in a number of ways. First, the pooled cross-section and time series data allow us to estimate the growth-environment-trade-financial development relationships over a long period of time for several countries. Second, any country-specific effect can be controlled by using an appropriate GMM procedure. And finally, our panel estimation procedure can control for potential endogeneity thatmay emerge from explanatory variables. 


\subsection{Panel unit root tests}

As it is now well-known the econometric literature on panel unit roots roots tests now distinguishes between the $1^{\text {st }}$ generation tests (see e.g. Levin, Lin and Chu, 2002; Im, Pesaran and Shin, 2003) developed on the assumption of cross-section independence (except for common time effects), and the $2^{\text {nd }}$ generation tests (see e.g. Pesaran, 2007) that allow, in a variety of forms and degrees, the dependence that might prevail across the different units in the panel. Furthermore, as put in evidence for instance by Banerjee et al. (2005), panel unit root tests of the $1^{\text {st }}$ generation can lead to spurious results (because of size distortions) if there exists significant degrees of error cross-section dependence and this is ignored. Consequently, the implementation of $2^{\text {nd }}$ generation panel unit root tests is desirable only when it has been clearly established that the panel is effectively subject to a significant degree of error crosssection dependence. In the cases where cross-section dependence is not sufficiently high, loss of power might result if $2^{\text {nd }}$ generation panel unit root tests that allow for cross-section dependence are used. As this is precisely the case here we privilege below panel unit root tests of the $1^{\text {st }}$ generation (see footnote 1 in section 4.2 for further details on this issue).

Therefore, we begin our framework by performing the panel unit root test proposed by Levin et al. (LLC) (2002) and Im et al. (IPS) (2003). Both of LLC and IPS are based on the Augmented Dickey-Fuller principle.

Levin et al. (2002) considerd the following basic Augmented Dickey-Fuller model :

$$
\Delta X_{i, t}=\alpha_{i}+\beta_{i} X_{i, t-1}+\sum_{j=1}^{p_{i}} \mu_{i, j} \Delta X_{i, t-j}+\varepsilon_{i, t}
$$

where $\Delta$ is the first difference operator, $X_{i, t}$ is the dependent variable $i$ over period $t$, and the $\varepsilon_{i, t}$ is a white-noise disturbance with a variance of $\sigma_{i}^{2}$. Both $\beta_{i}$ and the lag order $\mu$ in Eq. (11) are permitted to vary across sections (countries). Hence, they assumed

$$
\left\{\begin{array}{l}
H_{0}: \beta_{i}=0 \\
H_{1}: \beta_{i} \prec 0
\end{array}\right.
$$

According to the LLC test, compared with the single-equation Augmented DickeyFuller test, the panel method sensibly rises power in finite samples. The proposed model is as follows:

$$
\Delta X_{i, t}=\alpha_{i}+\beta X_{i, t-1}+\sum_{j=1}^{P_{i}} \mu_{i, j} \Delta X_{i, t-j}+\varepsilon_{i, t}
$$

They also assumed 
$\left\{\begin{array}{l}H_{0}: \beta_{1}=\beta_{2}=\ldots \ldots .=\beta=0 \\ H_{1}: \beta 1=\beta_{2}=\ldots \ldots=\beta \prec 0\end{array} ;\right.$ where the statistic of test is $t_{\beta}=\frac{\beta}{\sigma(\beta)}, \beta$ is the OLS estimate of $\beta$ in Eq. (12) and $\sigma(\beta)$ is its standard error.

Im et al. (2003) proposed a testing procedure based on the mean group approach and also on the Augmented Dickey-Fuller regression presented by Eq. (11). By contrast, the null and alternative hypotheses are not similar to the LLC test, where the rejection of the null hypothesis indicates that all the series are stationary. Now, we have $\mathrm{H}_{0}: \beta_{1}=\beta_{2}=\ldots=\beta_{\mathrm{N}}=0 \quad$ vs. $\quad \mathrm{H}_{1}$ : Some but not necessarily all $\beta_{\mathrm{i}} \prec 0$

The IPS test is calculated as the average of the t-statistic with and without trend. Alternative t-bar statistic for testing the null hypothesis of unit root for all individuals $\left(\beta_{\mathrm{i}}=0\right)$ is as follows

$$
\bar{t}=\frac{\sum_{i=1}^{N} t \beta_{i}}{N}
$$

where $t$ is the estimated Augmented Dickey-Fuller statistics from individual panel members; $\mathrm{N}$ is the number of individuals. Using Monte Carlo simulations, this test show that the t-bar $(\bar{t})$ is normally distributed under the null hypothesis. Accordingly, they then use estimates of its mean and variance to convert t-bar $(\bar{t})$ into a standard normal z-bar $(\bar{z})$ statistic which is given by:

$$
\bar{z}=\frac{\sqrt{N}\left(\bar{t}-E\left[\bar{t} \mid \beta_{i}=0\right]\right)}{\sqrt{\operatorname{var}\left[\bar{t} \mid \beta_{i}=0\right]}} \rightarrow N(0,1)
$$

where $E\left[\bar{t} \mid \beta_{i}=0\right]$ and $\operatorname{var}\left[\bar{t} \mid \beta_{i}=0\right]$ are the mean and variance of $t_{i t}$. Moreover, the IPS study shows that the standardized statistic converges weakly to the standard normal distribution, which allows for comparison with critical values of the distribution $\mathrm{N}(0,1)$. 


\section{Data and results}

\subsection{Data and descriptive statistics}

The sample used is annual data covering the period 1990-2011 for 12 MENA countries ; namely, Algeria, Bahrain, Egypt, Iran, Jordan, Kuwait, Morocco, Oman, Qatar, Saudi Arabia, Syria, and Tunisia which are considered for this panel analysis. The data are taken from the World Development Indicators (http://data.worldbank.org/indicator). The selection of the starting period was constrained by the availability of data. The variables are per capita GDP (constant 2005 US\$) measures the economic growth, per capita $\mathrm{CO}_{2}$ emissions (metric tons), per capita total energy consumption ( $\mathrm{kg}$ of oil equivalent) as a proxy of energy consumption, per capita gross fixed capital formation (constant 2005 US\$) as a proxy of capital stock, domestic credit to private sector as share of GDP as a proxy for financial development, total trade as share of GDP is the proxy of trade openness, urban population as share of total population is the proxy for urbanization, foreign direct investment net inflows as share of GDP is the proxy of foreign direct investment and consumer prices (annual \%) as a proxy of inflation.

The descriptive statistics of the different variables for individuals and also for the panel are given below in Table 1. On average, the highest levels of per capita GDP (28381.740), $\mathrm{CO}_{2}$ emissions (53.321) are found for Qatar, while the lowest of per capita GDP is for Syria, and per capita $\mathrm{CO}_{2}$ emissions (1.281) is for Morocco. In addition, the highest level of financial development (72.695) is for Jordan, while the lowest is for Qatar (2.835). Then, the highest level of trade (160.306) is for Bahrain, while the lowest is for Iran (46.860). Thereafter, Tunisia is the most volatile compared with the other countries in terms of economic output. It has the highest coefficient of variation $(0.214)$ as measured by the standard deviation-to-mean ratio. In termes of $\mathrm{CO}_{2}$ emissions, Oman is the most volatile because it has the highest coefficient of variation (0.392) compared with the other countries. The same patterns is found for financial development (0.969) and trade openness (0.224) for Algeria and Iran, respectively. 
Table 1

Summary statistics (before taking logarithm), 1990-2011.

\begin{tabular}{|c|c|c|c|c|c|c|c|c|c|c|}
\hline 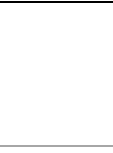 & $\begin{array}{l}\text { Descriptives } \\
\text { statistics }\end{array}$ & $\begin{array}{c}\text { Per capita GDP (constant } \\
2005 \text { USD) }\end{array}$ & $\begin{array}{l}\mathrm{CO}_{2} \text { emissions (metric } \\
\text { tons per capita) }\end{array}$ & $\begin{array}{c}\text { Financial } \\
\text { development (in } \\
\%)\end{array}$ & $\begin{array}{l}\text { Trade openness } \\
\text { (in \%) }\end{array}$ & $\begin{array}{l}\text { Per capitaCapital } \\
\text { stock (constant } \\
2005 \text { USD) }\end{array}$ & $\begin{array}{c}\text { ENC (kg of oil equivalent } \\
\text { per capita) }\end{array}$ & $\begin{array}{l}\text { Urbanization } \\
\text { (in\%) }\end{array}$ & $\begin{array}{l}\text { Inflation } \\
\text { (in\%) }\end{array}$ & $\begin{array}{l}\text { FDI } \\
\text { (in } \%)\end{array}$ \\
\hline \multirow[t]{3}{*}{ Algeria } & Means & 1908.692 & 3.152 & 13.352 & 57.016 & 2740.266 & 953.592 & 61.934 & 10.281 & 1.004 \\
\hline & Std. dev. & 212.142 & 0.234 & 12.943 & 8.387 & 313.657 & 122.749 & 6.656 & 10.595 & 0.634 \\
\hline & $\mathrm{CV}$ & 0.111 & 0.074 & 0.969 & 0.147 & 0.114 & 0.128 & 0.107 & 1.030 & 0.631 \\
\hline \multirow[t]{2}{*}{ Bahrain } & Means & 12298.53 & 25.423 & 52.266 & 160.306 & 20369.26 & 9122.009 & 88.402 & 1.146 & 7.132 \\
\hline & $\mathrm{CV}$ & 0.117 & 0.116 & 0.287 & 0.111 & 0.143 & 0.086 & 0.001 & 1.356 & 1.169 \\
\hline \multirow[t]{3}{*}{ Egypt } & Means & 1494.502 & 2.017 & 40.358 & 52.091 & 2575.714 & 707.562 & 43.058 & 9.163 & 2.416 \\
\hline & Std. dev. & 272.555 & 0.521 & 11.666 & 9.533 & 2207.125 & 149.250 & 0.240 & 5.369 & 2.684 \\
\hline & $\mathrm{CV}$ & 0.182 & 0.258 & 0.289 & 0.183 & 0.856 & 0.210 & 0.005 & 0.585 & 1.110 \\
\hline \multirow[t]{3}{*}{ Iran } & Means & 1727.876 & 6.009 & 26.573 & 46.860 & 3685.296 & 2071.401 & 63.821 & 19.127 & 0.647 \\
\hline & Std. dev. & 369.371 & 1.763 & 7.977 & 10.503 & 819.271 & 548.424 & 4.218 & 9.120 & 0.842 \\
\hline & $\mathrm{CV}$ & 0.213 & 0.293 & 0.300 & 0.224 & 0.222 & 0.264 & 0.066 & 0.476 & 1.301 \\
\hline \multirow[t]{3}{*}{ Jordan } & Means & 1956.190 & 3.446 & 72.695 & 126.401 & 2944.683 & 1085.146 & 79.253 & 4.492 & 5.953 \\
\hline & Std. dev. & 360.247 & 0.350 & 9.071 & 14.655 & 437.623 & 115.617 & 2.931 & 4.140 & 6.416 \\
\hline & $\mathrm{CV}$ & 0.184 & 0.101 & 0.124 & 0.115 & 0.148 & 0.106 & 0.036 & 0.921 & 1.077 \\
\hline \multirow[t]{3}{*}{ Kuwait } & Means & 21691.770 & 29.118 & 52.446 & 92.874 & 28953.580 & 9283.332 & 98.116 & 3.373 & 0.163 \\
\hline & Std. dev. & 2292.088 & 2.765 & 19.629 & 11.981 & 6262.777 & 2428.257 & 0.086 & 3.076 & 0.326 \\
\hline & $\mathrm{CV}$ & 0.105 & 0.094 & 0.374 & 0.129 & 0.216 & 0.261 & 0.008 & 0.911 & 2 \\
\hline \multirow[t]{3}{*}{ Morocco } & Means & 1413.937 & 1.281 & 44.259 & 64.412 & 1693.511 & 381.721 & 53.283 & 2.968 & 1.536 \\
\hline & Std. dev. & 248.795 & 0.216 & 14.785 & 10.081 & 287.764 & 73.347 & 2.507 & 2.241 & 1.371 \\
\hline & $\mathrm{CV}$ & 0.175 & 0.168 & 0.334 & 0.156 & 0.169 & 0.192 & 0.047 & 0.755 & 0.892 \\
\hline \multirow[t]{3}{*}{ Oman } & Means & 8992.859 & 10.892 & 33.706 & 86.800 & 12184.790 & 4064.466 & 71.228 & 3.105 & 1.685 \\
\hline & Std. dev. & 1567.892 & 4.276 & 8.608 & 6.777 & 3365.855 & 1575.096 & 1.863 & 3.558 & 2.076 \\
\hline & $\mathrm{CV}$ & 0.174 & 0.392 & 0.255 & 0.078 & 0.276 & 0.387 & 0.026 & 1.145 & 1.232 \\
\hline \multirow[t]{2}{*}{ Qatar } & Means & 28381.740 & 53.321 & 2.835 & 84.082 & 42766.160 & 16859.350 & 96.222 & 3.875 & 2.835 \\
\hline & Std. dev. & 4416.412 & 10.528 & 2.199 & 9.820 & 6833.614 & 2811.166 & 1.789 & 4.892 & 2.199 \\
\hline
\end{tabular}




\begin{tabular}{|c|c|c|c|c|c|c|c|c|c|c|}
\hline & $\mathrm{CV}$ & 0.155 & 0.197 & 0.775 & 0.116 & 0.159 & 0.166 & 0.018 & 1.262 & 0.775 \\
\hline \multirow[t]{3}{*}{ Saudi Arabia } & Means & 9300.450 & 15.098 & 29.326 & 76.696 & 15226.850 & 5258.383 & 79.808 & 2.008 & 2.093 \\
\hline & Std. dev. & 237.447 & 2.044 & 10.150 & 15.199 & 5147.935 & 734.700 & 1.685 & 2.846 & 3.209 \\
\hline & $\mathrm{CV}$ & 0.025 & 0.135 & 0.346 & 0.198 & 0.338 & 0.139 & 0.021 & 1.417 & 1.533 \\
\hline \multirow[t]{3}{*}{ Syria } & Means & 761.594 & 3.486 & 27.282 & 64.491 & 2292.020 & 1174.366 & 67.885 & 6.355 & 1.495 \\
\hline & Std. dev. & 154.126 & 0.452 & 17.318 & 0.989 & 1860.457 & 297.271 & 1.041 & 6.144 & 1.181 \\
\hline & $\mathrm{CV}$ & 0.202 & 0.129 & 0.634 & 0.015 & 0.811 & 0.253 & 0.015 & 0.966 & 0.789 \\
\hline \multirow[t]{3}{*}{ Tunisia } & Means & 2334.958 & 2.091 & 61.996 & 90.633 & 2885.232 & 764.809 & 63.118 & 4.050 & 2.819 \\
\hline & Std. dev. & 501.0915 & 0.281 & 5.258 & 9.105 & 653.041 & 113.745 & 2.537 & 1.544 & 1.931 \\
\hline & $\mathrm{CV}$ & 0.214 & 0.134 & 0.084 & 0.100 & 0.226 & 0.148 & 0.040 & 0.381 & 0.684 \\
\hline \multirow[t]{3}{*}{ Panel } & Means & 7688.591 & 12.944 & 41.038 & 83.555 & 11564.950 & 4310.512 & 72.177 & 5.829 & 2.481 \\
\hline & Std. dev. & 8842.616 & 15.575 & 20.152 & 33.143 & 13126.630 & 5017.059 & 16.343 & 7.099 & 3.949 \\
\hline & $\mathrm{CV}$ & 1.150 & 1.203 & 0.491 & 0.396 & 1.135 & 1.163 & 0.226 & 1.217 & 1.591 \\
\hline
\end{tabular}

Notes : Std. Dev.: indicates standard deviation, ENC: indicates per capita energy consumption, and FDI: indicates foreign direct investment. 


\subsection{Results of panel unit root and cointegration tests}

In panel data analysis, the panel unit root test must be taken first in order to identify the stationary properties of the relevant variables. There exist a number of methods for panel unit root tests. In this study, we choose two panel unit root tests of the 1 st generation, namely Levin-Lin-Chu (LLC) (2002), and Im-Pesaran-Shin (IPS) (2003) tests since no significant evidence of error cross-section dependence is found in the data ${ }^{2}$. The LLC test takes into account the heterogeneity of various sections, but it has low power in small samples because of the serial correlation, which cannot be completely eliminated. The IPS test considers the heterogeneity among the sections and also eliminates the serial correlation, thus has a strong ability of testing in small samples. The null hypothesis of the above two unit root tests is that there exist unit root (i.e. the variables are non-stationary), and the alternative hypothesis is that no unit root exists in the series (i.e. the variables are stationary).

Table 2a shows the results of the panel unit root tests for levels of variables. It can be seen from Table 2a that all variables in first difference are statistically significant under the LLC and IPS tests, indicating that all variables are integrated of order one, I(1) ${ }^{3}$.

Table 2a

Results of panel unit root tests.

\begin{tabular}{|c|c|c|c|c|c|c|c|c|}
\hline \multirow[t]{3}{*}{ Variables } & \multicolumn{4}{|c|}{ LLC test } & \multicolumn{4}{|c|}{ IPS test } \\
\hline & \multicolumn{2}{|c|}{ Level } & \multicolumn{2}{|l|}{ First difference } & \multicolumn{2}{|c|}{ Level } & \multicolumn{2}{|c|}{ First difference } \\
\hline & T-Statistics & $\mathrm{p}$-value & T-Statistics & p-value & T-Statistic & p-value & T-Statistics & p-value \\
\hline $\mathrm{Y}$ & $3.0768(0)$ & 1.0000 & $-10.6696(0)^{* * *}$ & 0.0000 & $1.9175(2)$ & 0.9430 & $-5.1015(0)^{* * *}$ & 0.0000 \\
\hline $\mathrm{C}$ & $-5.4006(0)^{* * *}$ & 0.0000 & $-10.4241(0)^{* * *}$ & 0.0000 & $2.3915(0)$ & 0.9987 & $-1.7215(0)^{* *}$ & 0.0273 \\
\hline FD & $-3.3680(1)^{* * *}$ & 0.0004 & $-13.5629(0)^{* * *}$ & 0.0000 & $-2.4998(1)^{* * *}$ & 0.0062 & $-2.7010(0)^{* * * *}$ & 0.0032 \\
\hline $\mathrm{T}$ & $-3.2838(0)^{* * *}$ & 0.0005 & $-9.37281(0)^{* * *}$ & 0.0000 & $-2.1905(0)^{* *}$ & 0.0290 & $-2.3772(1)^{* *}$ & 0.0048 \\
\hline K & $4.0184(1)$ & 1.0000 & $-12.1648(0)^{* * * *}$ & 0.0000 & $2.3861(0)$ & 0.7448 & $-1.1839(1)^{* * *}$ & 0.0062 \\
\hline $\mathrm{E}$ & $-2.1756(0)^{* *}$ & 0.0148 & $-4.9771(0)^{*}$ & 0.0061 & $-2.0214(1)^{*}$ & 0.0731 & $-5.6577(1)^{* * *}$ & 0.0000 \\
\hline UR & $-3.0206(0) * * *$ & 0.0013 & $-11.3882(0) * * *$ & 0.0000 & $-2.5897(0)^{* * *}$ & 0.0032 & $-2.9670(1)^{* * * *}$ & 0.0012 \\
\hline IF & $-5.5663(0)^{* * *}$ & 0.0000 & $-7.1186(0)^{*}$ & 0.0077 & $-3.9930(0)^{* * *}$ & 0.0000 & $-7.2446(1)^{* * *}$ & 0.0000 \\
\hline FDI & $-7.4554(0)^{* * *}$ & 0.0000 & $-10.3024(0)^{* * *}$ & 0.0000 & $-5.6239(0)^{* * *}$ & 0.0000 & $-4.4092(0)^{* * *}$ & 0.0000 \\
\hline
\end{tabular}

Notes: All panel uni troot tests were performed with restricted intercept and trend for all variables. In addition, Lag length of variables is shown in small parentheses. ${ }^{*},{ }^{* *}$, and ${ }^{* * *}$ indicate significance at the $1 \%, 5 \%$, and $10 \%$ levels, respectively.

\footnotetext{
${ }^{2}$ Before carrying out the $1^{\text {st }}$ generation panel unit-root tests, we implemented the simple test of Pesaran (2004) and have computed the $\mathrm{CD}$ statistic to test for the presence of cross-section dependence in the data. This test is based on the average of pair-wise correlation coefficients of the OLS residuals obtained from standard augmented Dickey-Fuller regressions for each individual unit. Its null hypothesis is cross-sectional independence and it follows asymptotically a two-tailed standard normal distribution. The null hypothesis is never rejected for all series in our panel sets, regardless of the number of lags (up to four lags) at the five and ten percent level of significance. Therefore, the members of our panel are not-cross-sectionally correlated, and any $2^{\text {nd }}$ generation panel unit root test (assuming cross-country dependence), would be flawed and cannot be used in our investigation.

${ }^{3}$ Note that just that just for a comparison purpose, we also computed the 2nd generation panel unit root test by Pesaran (2007) whose null hypothesis is the unit root for all countries. Although the Cross-sectionally augmented IPS statistics (CIPS) should of course not be computed (if the time series are cross-section independent as it is the case here), results support the existence of a unit root in all series under consideration. This confirms previous results obtained with the 1st generation panel unit root tests of Levin-Lin-Chu (LLC) (2002), and Im-Pesaran-Shin (IPS) (2003).
} 
Given that all our series are non-stationary and integrated of order 1, the next step is to test for the existence of cointegration between them. For this purpose, we implement the wellknown panel cointegration tests proposed by Pedroni (1999, 2004 whose null hypothesis is joint non-cointegration.

The computation of the seven test statistics proposed by Pedroni assumes crosssectional independence across individual units (apart from common time effects), an assumption that is verified here. These statistics can be grouped into either parametric or nonparametric statistics, depending on the way that autocorrelation and endogeneity bias are accounted for. In our study, we are only concerned with the parametric version of the statistics, i.e. the normalized bias and the pseudo t-ratio statistics, and with the ADF test statistics in particular. These test statistics are defined by pooling the individual tests, so that they belong to the class of between-dimension test statistics (see Pedroni, 1999, 2004 for further details).

Table $2 \mathrm{~b}$ reports the results of the panel data cointegration tests by Pedroni. More specifically, we test for cointegration between the differences variables included in each of the Eq. (7) to (10) associated to our growth-environment-trade and financial model. For all equations considered, conclusions of the test are straightforward. Indeed, it clearly emerges from P-values given in Table $2 b$ that in all cases the null hypothesis of no cointegration between variables of the four equations cannot be rejected by the test statistics. This results holds whatever the level of significance chosen $(1 \%, 5 \%$, or $10 \%)$ and clearly indicates that the variables included in our four equations are not cointegrated ${ }^{4}$.

Table 2b

Panel cointegration test results between the variables included in Eq. (7) to (10) (Pedroni, 1999; 2004).

\begin{tabular}{lcc}
\hline & ADF-stat & P-value \\
\hline Model including the variables of Eq. (7) & 0.37 & 0.64 \\
Model including the variables of Eq. (8) & 0.12 & 0.54 \\
Model including the variables of Eq. (9) & -0.98 & 0.16 \\
Model including the variables of Eq. (10) & -1.12 & 0.13 \\
\hline
\end{tabular}

Notes: i) All specifications includes a constant term.

ii) As the tests are one-sided, a calculated statistic smaller than the critical value $(-1.65$ at $5 \%)$ leads to the rejection of the null hypothesis of no cointegration

\footnotetext{
${ }^{4}$ Notice that for a comparison purpose, we also computed the bootstrap distribution of Pedroni's test statistics, thereby generating data-specific critical values as in Banerjee and Carrion-i-Silvestre (2006). These critical values are appropriate in the case of cross-sectional dependence (an assumption which was previously rejected for our dataset). We report that the null hypothesis of non-cointegration for all countries is still not rejected for the variables included in Eq. (7) to Eq. (10).
} 


\subsection{Regression results and Discussions}

While estimating the four-way linkages between $\mathrm{CO}_{2}$ emissions, financial development, trade and economic growth, $\mathrm{K}, \mathrm{Y}^{2}$, E, UR, IF and FDI are included as instrumental variables.

In addition, before running regressions, some specific tests have been audited. According to Newey (1985) and Smith and Blundell (1986), two important specification tests are used for simultaneous-equation regression models: test of endogeneity/exogeneity and test of overidentifying restrictions. First, the Durbin-Wu-Hausman (DWH) test was used to test the endogeneity for all three equations. The null hypothesis of the DWH endogeneity test is that an ordinary least squares (OLS) estimator of the same equation would yield consistent estimates: that is, an endogeneity among the regressors would not have deleterious effects on OLS estimates. A rejection of the null indicates that endogenous regressors' effects on the estimates are meaningful, and instrumental variables techniques are required. Second, we may test the overidentifying restrictions in order to provide some evidence of the instruments' validity. The instruments' validity is tested using the Hansen test by which the null hypothesis of overidentifying restrictions cannot be rejected. That is, the null hypothesis that the instruments are appropriate cannot be rejected.

Based on the above diagnostic tests, the estimated coefficients of Eqs. (7) to (10) are given in Tables $3,4,5$ and 6 .

The empirical results about Eq. (7) are presented in Table 3, which shows that per capita $\mathrm{CO}_{2}$ emissions have a negative and significant impact on per capita GDP for Egypt, Iran, Kuwait, Morocco, Oman, and Tunisia. This implies that economic growth is elastic with respect to $\mathrm{CO}_{2}$ emissions, and a $1 \%$ increase in environmental degradation decreases economic growth within a range of $0.169 \%$ (Tunisia) to $0.519 \%$ (Kuwait). For the remaining countries, no significant relationship is found. For the panel result, per capita $\mathrm{CO}_{2}$ emissions have a negative and significant impact on economic growth at $1 \%$ level. The magnitude of 0.233 implies that a $1 \%$ increase in $\mathrm{CO}_{2}$ emissions decreases economic growth by around $0.23 \%$. This result is consistent with the findings of Jayanthakumaran et al. (2012).

The Coefficient of financial development is positive and significant for 6 countries out of 12. Only for Algeria, Egypt, Iran, Jordan, Morocco, and Tunisia, it significantly affects per capita GDP, however no significant relationship is found for the rest of countries. This suggests that economic growth is elastic with respect to financial development, and a $1 \%$ increase in financial development increases economic growth within a range of $0.086 \%$ (Algeria) to $0.362 \%$ (Jordan). For the panel result, we find that the effect of nuclear energy 
consumption on economic growth is statistically significant at the 5\% level. The magnitude of 0.177 implies that a $1 \%$ increase in nuclear energy consumption increases the real income of the selected countries by around $0.18 \%$. This indicates that an increase in financial development tends to promote economic growth. Hence, sound and developed financial system can attract investors, boost the stock market and improve the economic growth (Shahabaz and Lean, 2012).

Table 3

Simultaneous equations GMM-estimation for Eq. 7.

\begin{tabular}{|c|c|c|c|c|c|}
\hline \multirow{3}{*}{ Independent variables } & \multicolumn{5}{|c|}{ Dependent variable : Economic growth } \\
\hline & Constant & $\mathrm{C}$ & FD & $\mathrm{T}$ & $\mathrm{K}$ \\
\hline & $0.916 * * * \quad(0.069)$ & $(0.813)$ & $0.086^{* *} \quad(0.017)$ & $0.135^{*} \quad(0.001)$ & $0.761^{*}(0.000)$ \\
\hline Bahrain & $0.866 * * \quad(0.041)$ & $(0.559)$ & $(0.635)$ & $0.355 * * * \quad(0.065)$ & $0.233^{*} \quad(0.009)$ \\
\hline Egypt & $(0.000)$ & $-0.423 *$ & $(0.002)$ & $-0.079 * * \quad(0.016)$ & $(0.463)$ \\
\hline Iran & $(0.008)$ & $-0.271 * * \quad(0.022)$ & $0.259 * * \quad(0.011)$ & $(0.676)$ & $0.555^{*} \quad(0.003)$ \\
\hline Jordan & $-3.555^{*}$ & $(0.167)$ & $0.362 * \quad(0.001)$ & $0.187 * * *(0.080)$ & $0.314 *(0.005)$ \\
\hline Kuwait & $(0.000)$ & $-0.519 *$ & $(0.399)$ & $(0.402)$ & $0.087 \quad(0.212)$ \\
\hline Morocco & $0.455 * * * \quad(0.087)$ & $-0.284 * * \quad(0.027)$ & $0.250 * * * \quad(0.075)$ & $0.229 * * * \quad(0.057)$ & $0.277 * *(0.042)$ \\
\hline Oman & $-2.232 * \quad(0.000)$ & $-0.253 * * \quad(0.036)$ & $0.026 \quad(0.268)$ & $-0.168 * * \quad(0.011)$ & $0.297 * * *(0.078)$ \\
\hline Qatar & $-1.804 * * *(0.088)$ & $-0.089 \quad(0.192)$ & $(0.183)$ & $0.377^{*} \quad(0.000)$ & $0.746^{*}(0.003)$ \\
\hline Saudi Arabia & $8.905^{*} \quad(0.000)$ & $(0.106)$ & $(0.138)$ & $(0.000)$ & $0.104 * *(0.031)$ \\
\hline Syria & $2.331 * * \quad(0.043)$ & $-0.099 \quad(0.224)$ & $(0.109)$ & $-0.119 \quad(0.175)$ & $-0.026 \quad(0.721)$ \\
\hline Tunisia & $2.852 * * * \quad(0.087)$ & $-0.169 * * \quad(0.033)$ & $0.213 * * \quad(0.021)$ & $0.203^{* * *}(0.076)$ & $0.103 \quad(0.109)$ \\
\hline Panel & $(0.000)$ & $-0.233^{*}$ & $0.199 *$ & $0.176^{* * *}(0.079)$ & $0.209 * *(0.044)$ \\
\hline Hansen test (p-value) & \multicolumn{5}{|c|}{$24.870(0.104)$} \\
\hline DWH test (p-value) & \multicolumn{5}{|c|}{$5.453(0.001)$} \\
\hline
\end{tabular}

In addition, trade openness has a significant impact on per capita GDP for 9 countries out of 12. Only for Algeria, Bahrain, Jordan, Morocco, Qatar, Saudi Arabia, and Tunisia, it positively affects economic growth, however for Egypt and Oman it has a significant negative impact. This suggests that an increase in trade openness tends to decrease economic growth in Egypt and Oman. From the elasticities, it can also be inferred that due to the increase in trade openness, growth goes down more in Oman than in Egypt $(0.168>0.079)$. The panel estimation indicates that trade openness has a positive and sifnificant impact on per capita GDP at $10 \%$ level. The magnitude of 0.176 implies that a $1 \%$ rise in trade openness raises economic growth by around $0.18 \%$.

Finally, the coefficient of capital is positive and significant for 8 countries out of 12 . Only for Egypt, Kuwait, Syria and Tunisia no significant relationship is found. For the panel result, it has a positive and significant impact on per capita GDP at the 5\% level. This implies that a $1 \%$ increase in capital increases economic growth by around $0.21 \%$. The result is consistent with the findings of Omri (2013). 
Table 4

Simultaneous equations GMM-estimation for Eq. 8.

\begin{tabular}{|c|c|c|c|c|c|c|c|c|c|c|c|}
\hline \multirow{3}{*}{$\begin{array}{l}\text { Independent variables } \\
\text { Algeria }\end{array}$} & \multicolumn{11}{|c|}{ Dependent variable : $\mathrm{CO}_{2}$ emissions } \\
\hline & \multirow{2}{*}{\begin{tabular}{|c|} 
Constant \\
$-4.999^{* *}(0.037)$
\end{tabular}} & $\mathrm{Y}$ & \multicolumn{2}{|c|}{ FD } & \multirow{2}{*}{\multicolumn{2}{|c|}{$\frac{\mathrm{T}}{0.318^{* *}(0.015)}$}} & \multicolumn{2}{|c|}{$\mathrm{Y}^{2}$} & E & \multicolumn{2}{|c|}{ UR } \\
\hline & & $(0.131)$ & 0.096 & $(0.378)$ & & & -0.138 & $(0.116)$ & $0.178 * * *(0.099)$ & 0.061 & $(0.421)$ \\
\hline Bahrain & $2.344 * * *(0.091)$ & $(0.244)$ & -0.282 & $(0.167)$ & $0.484 *$ & $(0.001)$ & -0.083 & $(0.531)$ & $0.193 * * * \quad(0.069)$ & 0.105 & $(0.211)$ \\
\hline Egypt & $7.189 * *(0.022)$ & $0.189 * * *(0.071)$ & 0.125 & $(0.233)$ & 0.113 & $(0.187)$ & $-0.265^{* *}$ & $(0.013)$ & $(0.165)$ & $0.321 * *$ & $(0.039)$ \\
\hline Iran & $-10.213 *(0.000)$ & $0.560 * \quad(0.002)$ & 0.070 & $(0.343)$ & 0.170 & $(0.219)$ & $-0.462 *$ & $(0.003)$ & $0.318 * *$ & $0.146^{* * * *}$ & $(0.052)$ \\
\hline Jordan & $-4.312 * *(0.012)$ & $(0.139)$ & $-0.178 * * *$ & $(0.055)$ & 0.137 & $(0.123)$ & 0.166 & $(0.218)$ & $(0.109)$ & -0.210 & $(0.129)$ \\
\hline Kuwait & $-7.310^{*} \quad(0.000)$ & $0.348 * \quad(0.005)$ & 0.161 & $(0.121)$ & 0.082 & $(0.209)$ & $-0.133^{* *}$ & $(0.047)$ & $0.202 * \quad(0.008)$ & $0.189^{* *}$ & $(0.044)$ \\
\hline Morocco & $-12.198 *(0.000)$ & $0.199 * *(0.025)$ & 0.141 & $(0.133)$ & 0.166 & $(0.197)$ & -0.091 & $(0.318)$ & $0.279^{* * *}(0.821)$ & $0.222^{* * *}$ & $(0.068)$ \\
\hline Oman & $-9.444 * \quad(0.007)$ & $0.387 * * \quad(0.018)$ & -0.190 & $(0.162)$ & 0.099 & $(0.217)$ & 0.112 & $(0.178)$ & $(0.347)$ & 0.277 & $(0.188)$ \\
\hline Qatar & $-6.367 * *(0.046)$ & $0.349 * \quad(0.000)$ & $0.211^{* *}$ & $(0.029)$ & $0.308^{* *}$ & $(0.011)$ & $-0.156^{* *}$ & $(0.083)$ & $(0.126)$ & 0.181 & $(0.236)$ \\
\hline Saudi Arak & $18.356 *(0.000)$ & $0.313^{*} \quad(0.001)$ & 0.144 & $(0.167)$ & 0.083 & $(0.471)$ & $-0.192^{* * *}$ & $(0.053)$ & $0.188^{* * *}(0.072)$ & $0.193 * *$ & $(0.038)$ \\
\hline Syria & $12.850 *(0.000)$ & $0.194 * * *(0.059)$ & 0.089 & $(0.341)$ & 0.110 & $(0.289)$ & 0.055 & $(0.481)$ & $0.149 * * *(0.050)$ & 0.169 & $(0.203)$ \\
\hline Tunisia & $-5.019 * *(0.023)$ & $0.193 * * *(0.061)$ & -0.102 & $(0.189)$ & 0.173 & $(0.145)$ & -0.098 & $(0.523)$ & $0.172 * * *(0.044)$ & 0.211 & $(0.105)$ \\
\hline Panel & $-4.024 * *(0.010)$ & $0.469 *$ & -0.199 & $(0.137)$ & $0.193^{* *}$ & $*(0.104)$ & $-0.193^{* * *}$ & $(0.067)$ & $0.488^{*}$ & 0.090 & $(0.216)$ \\
\hline Hansen test (p-value) & & & & & 4.591 & $1(0.294)$ & & & & & \\
\hline DWH test (p-value) & & & & & & $5(0.021)$ & & & & & \\
\hline
\end{tabular}

Notes : Values in parentheses are the estimated p-values. Hansen J-test refers to the over-identification test for the restrictions in GMM estimation. DWH-test is the Durbin-Wu-Hausman test for endogeneity. ${ }^{*},{ }^{* *}$, and ${ }^{* * *}$ indicate significance at the $1 \%, 5 \%$, and $10 \%$ levels, respectively.

Table 4 presents the estimated results about Eq. (8). It appears that per capita GDP has a positive and statistically significant impact on per capita $\mathrm{CO}_{2}$ emissions for 9 countries out of 12 . This implies that a $1 \%$ increase in per capita GDP increases $\mathrm{CO}_{2}$ emissions by around $0.19 \%, 0.60 \%, 0.35 \%, 0.20 \%, 0.40 \%, 0.35 \%, 0.31 \%, 019 \%$ and $0.19 \%$ for Egypt, Iran, Kuwait, Morocco, Oman, Qatar, Saudi Arabia, Syria and Tunisia, respectively. For the remaining countries, no significant relationship is found. The panel result shows that per capita GDP has a positive and significant impact on per capita $\mathrm{CO}_{2}$ emissions at the $1 \%$ level. The magnitude of 0.469 indicates that a $1 \%$ increase in per capita GDP increases $\mathrm{CO}_{2}$ emissions by around $0.47 \%$. This implies that an increase in economic growth tends to increase the environment degradation. The results are consistent with the findings of Halicioglu (2009) for Turkey; Fodha and Zaghdoud (2010) for Tunisia; Wang et al. (2011) for China; Arouri et al. (2012) for 12 MENA countries; Jayanthakumaran et al. (2012) for both China and India; Saboori et al. (2012) for Malaysia; and Lee (2013) for G20 countries.

Regarding the financial development variable, it is found that financial development has a significant impact only for 2 countries out of 12 . Only for Qatar, it positively affects per capita $\mathrm{CO}_{2}$ emissions, however for Jordan it has a negative impact. This result is consisting with the findings of Tamazian et al. (2009), Sadorsky (2010) and Zhang (2011). For the remaining countries, no significant relationship is found. For the panel result, it has an insignificant negative impact on per capita $\mathrm{CO}_{2}$ emisssions. The result is in line with Ozturk and Acaravci (2013) for Turkey. 
In addition, trade openness has a positive and significant impact on $\mathrm{CO}_{2}$ emissions only for 3 countries out of 12 . This implies that a $1 \%$ increase in foreign trade to GDP ratio increases $\mathrm{CO}_{2}$ emissions by around $0.32 \%, 0.48 \%$, and $0.31 \%$, for Algeria, Bahrain, and Qatart, respectively. For the remaining countries, no significant relationship is found. The panel estimation shows that openness has a positive and significant impact on $\mathrm{CO}_{2}$ emissions at $10 \%$ level. It shows that an increase in foreign trade to GDP ratio results in an increase in per capita $\mathrm{CO}_{2}$ emissions. The result is in line with Managi et al. (2009). They insisted on the importance of foreign trade in determining the level of $\mathrm{CO} 2$ emissions. In their analysis, they attempted to analyze the emission generated in the transport sector. They concentrated on China's export and found that trade plays an important role in generating emission in the transport sector and that greater emissions is attributable to exports rather than to imports.

The coefficient of the square of GDP is negative and statistically significant only for Egypt, Iran, Kuwait, Qatar and Saudi Arabi. These results support the validity of EKC hypothesis in these four countries. For the panel result, the square of GDP has negative and significant impact on $\mathrm{CO}_{2}$ emissions. It means that the level of per capita $\mathrm{CO}_{2}$ emissions initially increases with per capita GDP, until it reaches its stabilization point, any increase in per capita GDP likely reduces the per capita carbon emissions. The result is consisting with the finding of Saboori et al. (2012) and Ozturk and Acaravci (2013). For the panel result, no significant relationship is found.

Thereafter, the coeifficient of per capita energy consumption is posititive and statistically significant for all the countries, except for Egypt, Jordan, Oman and Qatar. This implies that per capita $\mathrm{CO}_{2}$ emissions are elastic with respect to per capita energy consumption, and a $1 \%$ increase in the use of energy increases environmental degradation within a range of $0.149 \%$ (Syria) to $0.318 \%$ (Iran). For the panel estimation, per capita energy consumption has a positive and significant impact on per capita $\mathrm{CO}_{2}$ emissions at $1 \%$ level. The magnitude of 0.488 implies that a $1 \%$ rise in energy consumption increases $\mathrm{CO}_{2}$ emissions by $0.49 \%$. This implies that an increase in energy consumption increase the environment degradation. This finding is in line with Soytas et al. (2007) for United States; Halicioglu (2009) for Turkey; Zhang and Cheng (2009) for China, Arouri et al. (2012) for MENA countries.

Finally, the urbanization variable has a positive and significant effect on per capita $\mathrm{CO}_{2}$ emissions only for 5 countries out of 12 . This implies that a $1 \%$ increase in urbanization increases per capita $\mathrm{CO}_{2}$ emissions by around $0.32 \%, 0.15 \%, 0.19 \%, 0.22 \%$, and $0.19 \%$, for Egypt, Iran, Kuwait, Morocco and Saudi Arabia, respectively. This indicates that an increase 
in the urbanization tends to increase per capita $\mathrm{CO}_{2}$ emissions in these five countries. This result is consistent with findings of Hossain (2011). For the panel estimation, urbanization has no significant impact on the enevironmental degradation for the region as a whole.

The empirical results about Eq. (9) are presented in Table 5, which shows that per capita GDP has a positive and significant impact on the level of financial development for 8 countries out of 12 . This implies that a $1 \%$ increase in per capita GDP increases financial development by around $0.20 \%, 0.25 \%, 0.31 \%, 0.26 \%, 0.18 \%, 0.25 \%, 0.45 \%$, and $0.24 \%$ for Algeria, Egypt, Iran, Jordan, Morocco, Qatar, Saudi Arabia, and Tunisia, respectively. For the remaining countries, no significant relationship is found. The panel result shows that per capita GDP has an insignificant impact on financial development. This implies that an increase in economic growth does not exert an effect on the level of financial development.

Table 5

Simultaneous equations GMM-estimation for Eq. 9.

\begin{tabular}{|c|c|c|c|c|c|c|}
\hline \multirow[b]{2}{*}{ Independent variables } & \multicolumn{6}{|c|}{ Dependent variable : Financial development } \\
\hline & Constant & $\mathrm{Y}$ & $\mathrm{C}$ & $\mathrm{T}$ & & IF \\
\hline Algeria & $-5.078 * * \quad(0.016)$ & $0.203 * * * \quad(0.054)$ & $\begin{array}{ll}-0.069 & (0.298)\end{array}$ & $0.366^{* * *}$ & $(0.099)$ & $-0.255 * * \quad(0.032)$ \\
\hline Bahrain & $16.542^{*}$ & $0.143 \quad(0.223)$ & $-0.179 * * *(0.082)$ & -0.087 & $(0.311)$ & $-0.240 * *(0.032)$ \\
\hline Egypt & $8.145^{*}$ & $0.249 * *$ & $-0.396 * \quad(0.002)$ & 0.117 & $(0.145)$ & $-0.061 \quad(0.187)$ \\
\hline Iran & $-10.158^{*} \quad(0.003)$ & $(0.007)$ & $-0.209^{* *}(0.026)$ & $0.274 * * *$ & $(0.071)$ & $-0.189 * * \quad(0.037)$ \\
\hline Jordan & $-4.361^{* *} \quad(0.048)$ & $0.255^{* *}$ & $-0.121 \quad(0.172)$ & 0.045 & $(0.374)$ & $-0.088 \quad(0.216)$ \\
\hline Kuwait & $-8.135^{* * * *}(0.074)$ & $0.089 \quad(0.532)$ & $(0.156)$ & 0.178 & $(0.176)$ & $-0.165 \quad(0.108)$ \\
\hline Morocco & $4.823^{* *} \quad(0.018)$ & $0.183^{* * * *}(0.068)$ & $-0.388^{*}$ & 0.063 & $(0.278)$ & $-0.195 * * *(0.053)$ \\
\hline Oman & $-7.779 * * \quad(0.011)$ & $0.099 \quad(0.133)$ & $(0.367)$ & 0.081 & $(0.255)$ & $(0.105)$ \\
\hline Qatar & $7.277 *$ & $(0.006)$ & $-0.187 * * \quad(0.048)$ & 0.111 & $(0.301)$ & $(0.281)$ \\
\hline Saudi Arabia & $3.487 * * * \quad(0.087)$ & $0.451^{* *}$ & $-0.095 \quad(0.180)$ & $0.266^{*}$ & $(0.005)$ & $-0.142 * * \quad(0.018)$ \\
\hline Syria & $-11.239^{*} \quad(0.000)$ & $0.189 \quad(0.103)$ & $(0.107)$ & 0.182 & $(0.128)$ & $-0.199 * * *(0.052)$ \\
\hline Tunisia & $6.127 *$ & $0.240 * * * \quad(0.070)$ & $(0.222)$ & $-0.213^{* *}$ & $(0.019)$ & $-0.196 * * *(0.059)$ \\
\hline Panel & $-2.306^{*} \quad(0.008)$ & $0.071 \quad(0.214)$ & $(0.111)$ & $0.443^{*}$ & $(0.009)$ & $-0.177 * * * \quad(0.059)$ \\
\hline Hansen test (p-value) & & & $15.521(0.223)$ & & & \\
\hline DWH test (p-value) & & & $3.144(0.013)$ & & & \\
\hline
\end{tabular}

Notes: Values in parentheses are the estimated p-values. Hansen J-test refers to the over-identification test for the restrictions in GMM estimation. DWH-test is the Durbin-Wu-Hausman test for endogeneity. ${ }^{*},{ }^{* * *}$, and ${ }^{* * * *}$ indicate significance at the $1 \%, 5 \%$, and $10 \%$ levels, respectively.

Regarding the pollutant variable, we find that per capita $\mathrm{CO}_{2}$ emissions have a negative and significant impact on financial development only for 5 countries out of 12 . This implies that the level of financial development is elastic with respect to $\mathrm{CO}_{2}$ emissions, and a $1 \%$ increase in environmental degradation decreases financial development within a range of $0.179 \%$ (Bahrain) to $0.396 \%$ (Egypt). For the remaining countries, no significant relationship is found. For the panel result, per capita $\mathrm{CO}_{2}$ emissions have no significant impact on financial development. This indicates that financial development in MENA countries has not taken place at the expense of per capita $\mathrm{CO}_{2}$ emissions. This result is consistent with the findings of Shabaz (2013b) for Indonesia. 
In addition, trade openness has a significant impact on financial development for 3 countries out of 12. Only for Algeria and Iran, it positively affects financial development, however a negative relationship is found for Tunisia. For the rest of countries, no significant relationship is found. The panel estimation shows that tarde openness has a positive and significant impact on the level of financial development at $5 \%$ level. The magnitude of 0.443 implies that a $1 \%$ increase in trade openness increases financial development by around $0.24 \%$. This finding is in line with Yucel (2009) for Turkey.

Finally, the coefficient of inflation is negative and significant only for 7 countries out of 12. This implies that financial development is elastic with respect to inflation, and a $1 \%$ increase in the inflation rate decreases the level of financial development within a range of $0.142 \%$ (Saudi Arabia) to $0.255 \%$ (Algeria). For the panel estimation, the coeifficient of inflation is negative and significant at $10 \%$ level. The magnitude of 0.177 implies that a $1 \%$ increase in inflation decreases financial development by around $0.18 \%$. This result is consistent with the findings of Dehesa et al. (2007) for a panel of 120 countries and Zoli (2007) for a panel of emerging European countries.

Table 6

Simultaneous equations GMM-estimation for Eq. 10.

\begin{tabular}{|c|c|c|c|c|c|c|c|}
\hline \multirow{3}{*}{$\frac{\text { Independent variables }}{\text { Algeria }}$} & \multicolumn{7}{|c|}{ Dependent variable : Trade } \\
\hline & Constant & \multicolumn{2}{|c|}{$\mathrm{Y}$} & \multicolumn{2}{|c|}{$\mathrm{C}$} & FD & \multirow{2}{*}{$\begin{array}{c}\text { FDI } \\
0.179^{* *}(0.013)\end{array}$} \\
\hline & $\begin{array}{l}-5.616 * * \quad(0.018) \\
\end{array}$ & $0.289^{* * * *}$ & $(0.074)$ & -0.187 & $\begin{array}{ll}(0.109) \\
\end{array}$ & $0.378 * * * \quad(0.066)$ & \\
\hline Bahrain & $(0.000)$ & 0.146 & $(0.324)$ & -0.121 & $(0.219)$ & $0.090 \quad(0.318)$ & $0.047 \quad(0.399)$ \\
\hline Egypt & $-6.636^{*} \quad(0.002)$ & $0.410^{*}$ & $(0.000)$ & -0.045 & $(0.412)$ & $(0.004)$ & $(0.263)$ \\
\hline Iran & $-4.230^{* * *}(0.060)$ & $0.209^{* *}$ & $(0.012)$ & -0.187 *** & $(0.088)$ & $0.197 * *$ & $0.124 \quad(0.209)$ \\
\hline Jordan & $13.913^{*} \quad(0.003)$ & $0.177 * * *$ & $(0.081)$ & -0.093 & $(0.201)$ & $(0.000)$ & $0.274 * *(0.030)$ \\
\hline Kuwait & $(0.005)$ & 0.106 & $(0.199)$ & -0.211 & $(0.104)$ & $(0.189)$ & $0.059 \quad(0.288)$ \\
\hline Morocco & $-7.904 * \quad(0.000)$ & $0.272 * *$ & $(0.013)$ & $-0.199 * *$ & $(0.045)$ & $(0.001)$ & $0.299 *$ \\
\hline Oman & $-3.096 * * \quad(0.044)$ & 0.139 & $(0.110)$ & -0.065 & $(0.42)$ & $0.122 \quad(0.188)$ & $0.109 \quad(0.128)$ \\
\hline Qatar & $-4.212^{* * *}(0.081)$ & $0.532 *$ & $(0.002)$ & -0.129 & $(0.183)$ & $0.179 * * * \quad(0.051)$ & $0.292 * * *(0.077)$ \\
\hline Saudi Arabia & $-12.225^{*} \quad(0.000)$ & 0.124 & $(0.169)$ & -0.081 & $(0.290)$ & $0.233^{* *} \quad(0.020)$ & $0.189^{* * *}(0.092)$ \\
\hline Syria & $(0.000)$ & 0.089 & $(0.291)$ & -0.161 & $(0.107)$ & $(0.281)$ & $0.117 \quad(0.178)$ \\
\hline Tunisia & $4.117 * * \quad(0.038)$ & $0.198^{*}$ & $(0.007)$ & -0.091 & (0.306) & $0.271 * * \quad(0.010)$ & $0.188 * * *(0.082)$ \\
\hline Panel & $3.060 * * *(0.075)$ & $0.175 * * *$ & $(0.059)$ & -0.099 & $(0.146)$ & $0.195 * * \quad(0.042)$ & $0.211 * * \quad(0.046)$ \\
\hline Hansen test (p-value) & & & & 18.753 & $0.371)$ & & \\
\hline DWH test (p-value) & & & & 6.944 & 0.009) & & \\
\hline
\end{tabular}

Notes: Values in parentheses are the estimated p-values. Hansen J-test refers to the over-identification test for the restrictions in GMM estimation. DWH-test is the Durbin-Wu-Hausman test for endogeneity. ${ }^{*},{ }^{* *}$, and ${ }^{* * * *}$ indicate significance at the $1 \%, 5 \%$, and $10 \%$ levels, respectively.

Table 6 presents the estimated results about Eq. (10). It appears that per capita GDP has a positive and significant impact on foreign trade to GDP ratio for 7 countries out of 12 . This implies that a $1 \%$ increase in per capita GDP increases foreign trade to GDP ratio by around $0.29 \%, 0.41 \%, 0.21 \%, 0.18 \%, 0.28 \%, 0.53 \%$, and $0.20 \%$ for Algeria, Egypt, Iran, Jordan, Morocco, Qatar, and Tunisia, respectively. For the remaining countries, no significant 
relationship is found. The panel result shows that per capita GDP has a positive and significant impact on financial development at the $10 \%$ level. The magnitude of 0.175 indicates that a $1 \%$ increase in per capita GDP increases trade openness in the MENA region by around $0.18 \%$. This implies that an increase in economic growth tends to increase the level of foreign trade to GDP ratio.

In addition, the coeifficient of per capita $\mathrm{CO}_{2}$ emissions have a negative and significant impact on financial development only for Iran and Morocco. For the remaining countries, no significant relationship is found. From the elasticities, it can also be inferred that due to the increase in $\mathrm{CO}_{2}$ emissions, foreign trade to GDP ratio goes down more in Morocco than in Iran $(0.199>0.187)$. This result is consistent with the findings of al-mulali and Ting (2014) for six regions. For the panel estimation, we find that per capita $\mathrm{CO}_{2}$ emissions have no significant impact on trade liberalisation. This finding is in line with Kohler (2013) for Turkey.

The coeifficient of financial development is positive and significant for 8 countries out of 12 . This implies that a $1 \%$ increase domestic credit to private sector increases foreign trade to GDP ratio by around $0.38 \%, 0.33 \%, 0.20 \%, 0.50 \%, 0.31 \%, 0.18 \%, 23 \%$ and $0.27 \%$ for Algeria, Egypt, Iran, Jordan, Morocco, Qatar, Saudi Arabia, and Tunisia, respectively. For the remaining countries, no significant relationship is found. The panel result shows that the level of financial development has a positive and significant impact on foreign trade to GDP ratio at the 5\% level. The magnitude of 0.195 indicates that a $1 \%$ increase in financial development increases trade openness in the MENA region by around $0.20 \%$. This implies that an increase in financial development tends to increase the level of foreign trade to GDP ratio. The result is consistent with the findings of Menyah et al. (2014).

Finally, FDI has a positive and significant impact on trade openness for 6 countries out of 12. This implies that financial development is elastic with respect to FDI, and a $1 \%$ increase in the FDI rate increases the level of financial development within a range of $0.179 \%$ (Algeria) to $0.299 \%$ (Morocco). For the panel estimation, the coeifficient of FDI is positive and significant at 5\% level. The magnitude of 0.211 implies that a $1 \%$ increase in FDI increases financial development by around $0.21 \%$.

Overall, the above-discussed results regarding the individual cases can be summarized as follows. First, according to the causal relationship between $\mathrm{CO}_{2}$ emissions and economic growth, our results supported evidence of the feedback hypothesis for Egypt, Iran, Kuwait, Morocco, Omand, and Tunisia. The neutrality hypothesis is present for Algeria, Bahrain, and Jordan. The unidirectional causality running from economic growth to $\mathrm{CO}_{2}$ emissions is supported for 
Quatar, Saudi Arabia, and Syria. Second, according to the causal relationship between financial development and economic growth, we identified the feedback hypothesis for Algeria, Egypt, Iran, Jordan, Morocco, and Tunisia ; the neutrality hypothesis for Bahrain, Kuwait, Oman, and Syria ; and the unidirectional causality running from economic growth to financial development for Qatar and Saudi Arabia. Third, according to the causal linkage between financial development and $\mathrm{CO}_{2}$ emissions, we supported evidence of the feedback hypothesis only for Qatar; the neutrality hypothesis for Algeria, Kuwait, Oman, Saudi Arabia, Syria, and Tunisia ; the unidirectional causality running from financial development to $\mathrm{CO}_{2}$ emissions only for Jordan; and the undirectional causality running from $\mathrm{CO} 2$ emissions to financial development for Bahrain, Egypt, Iran, and Morocco. Fourth, according to the causal linkage between to trade openness and economic growth, we showed that there is a feedback hypothesis for Algeria, Egypt, Jordan, Morocco, Qatar, and Tunisia ; neutrality hypothesis for Kuwait and Syria; unidirectional causality running from trade openness to economic growth for Bahrain, Oman, and Saudi Arabia ; and unidirectional causality running from economic growth to trade openness only for Iran. Fifth, our findings supported also, according to causal relationship between trade and $\mathrm{CO}_{2}$ emissions, the neutrality hypothesis for Egypt, Jordan, Kuwait, Oman, Saudi Arabia, Syria, and Tunisia; the unidirectional causality running from trade openness to $\mathrm{CO}_{2}$ emissions for Algeria, Bahrain, and Qatar ; and the unidirectional causality running from $\mathrm{CO}_{2}$ emissions to trade openness for Iran and Morocco. Finally, according to the causality between trade openness and financial development, we showed that there is a feedback hypothesis for Algeria, Iran, Saudi Arabia, and Tunisia; a neutrality hypothesis for Bahrain, Kuwait, Oman, and Syria; and a unidirectional causality running from financial development to trade for Egypt, Jordan, Morocco, and Qatar.

Therefore, according to the collectively countries, we can conclude that there is: (i) a bi-directional causal relationship between carbon dioxide emissions and economic growth. This result is consistent with the findings of Halicioglu (2009); Soytas and Sari (2009), Arouri et al. (2012) and Omri et al. (2014); (ii) a bidirectional relationship between trade and economic growth implying that the two variables are interdependent. The result is in ligne with Belloumi (2014) and Nasreen and Anwar (2014); (iii) a bidirectional relationship between trade and financial development but strong causality running from trade to financial development; (iv) a unidirectional causal relationship running from financial development to economic growth; (v) a neutrality causal relationship between financial development and $\mathrm{CO}_{2}$ emissions ; and (vi) a unidirectional causalty running from trade openness to $\mathrm{CO}_{2}$ emissions. 
Fig. 1 summarizes the above results. These results corroborate the four-way linkages between financial development, environmental degradation, trade openness and economic growth in 12 MENA countries over the period of 1990-2011.

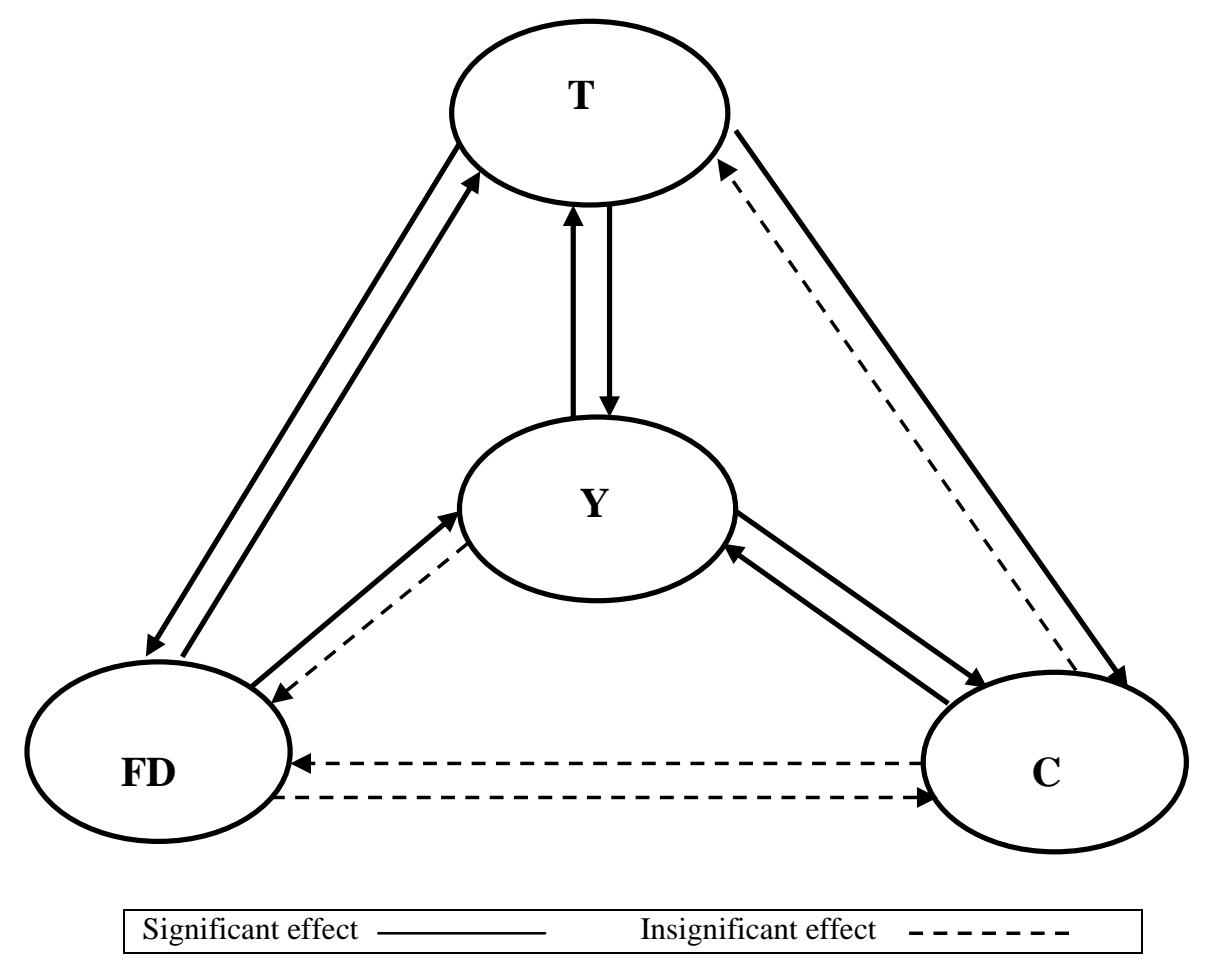

Fig. 1. The four-way linkages between finance-environment-trade-growth.

\section{Conclusions and Policy Implications}

This study investigated the causal linkages between $\mathrm{CO}_{2}$ emissions, financial development, trade, and economic growth using simultaneous-equation panel data models in case of 12 MENA countries over the period 1990-2011. We are motivated by the fact that there are no studies has investigated the four-way linkages between $\mathrm{CO}_{2}$ emissions, financial development, trade, and economic growth using four structural equations that allow one to simultaneously examine the impact of (i) $\mathrm{CO}_{2}$ emissions, financial development and other variables on economic growth; (ii) economic growth, financial development, trade and other variables on $\mathrm{CO}_{2}$ emissions.; (iii) economic growth, $\mathrm{CO}_{2}$ emissions, trade and other variables on financial development; and (iv) economic growth, $\mathrm{CO} 2$ emissions, financial development and other variables on trade.

The main findings show evidence of bidirectional causality between $\mathrm{CO} 2$ emissions and economic growth. Economic growth and trade openness are interrelated. Feedback hypothesis is validated between trade openness and financial development. Neutrality 
hypothesis is identified between $\mathrm{CO}_{2}$ emissions and financial development. Unidirectional causality running from financial development to economic growth and from trade openness to $\mathrm{CO}_{2}$ emissions is identified. Our empirical results also verified the existence of environmental Kuznets curve.

The main policy implications arising from our study can be presented as follows. The feedback between environmental degradation and economic growth implies that the environmental degradation has a causal impact on economic growth, and a persistent decline in environmental quality may exert a negative externality to the economy through affecting human health, and thereby it may reduce productivity in the long run. Therefore, carbon emissions can be reduced at the cost of economic growth or energy efficient technologies should be encouraged to enhance domestic production with the help of financial sector and import environment friendly technology from advanced countries. In addition, we argue with respect to financial development and carbon emission that higher level of financial system development and trade openness prop up technological innovations by increasing spending on energy conservation $R \& D$ which results in energy efficiency and hence it may lower emissions. In addition, the feedback effect between trade openness and economic growth also supports to adopt supplementary trade liberalization policies to reap optimal fruits of trade openness to sustain long run economic growth. The adoption of financial liberalization policies is also necessary to make trade openness and economic growth nexus sound as financial sector development leads exports and trade openness promotes economic economic growth and same is true from opposite side. Finally, the financial development exerts a positive impact on the economic growth. Economic policies, on the one hand, focus only on the development of the financial sector may not result in economic development where the financial sector follows economic growth in the MENA countries. On the other hand, the financial sector should provide sufficient resources by creating new instruments, institutions and organizations for the demand of real sector with the progress of economic development where the economic growth leads development of the financial sector. 


\section{References}

Ahlin, C., Pang, J. 2008. Are financial development and corruption control substitutes in promoting growth? Journal of Development Economics 86, 414-433.

Ang, J.B., 2007. $\mathrm{CO}_{2}$ emissions, energy consumption, and output in France. Energy Policy 35, 4772-4778.

Ang, J.B., 2008. Economic development, pollutant emissions and energy con-sumption in Malaysia. Journal of Policy Modeling 30, 271-278.

Ang, J.B., 2009. CO2 emissions, research and technology transfer in China. Ecol. Econ. 68, 2658-2665.

Anwar, S., Sun, S., 2011. Financial development, foreign investment and economic growth in Malaysia. Journal of Asian Economics 22, 335-342.

Apergis, N., Payne, J.E., 2009. Energy consumption and economic growth in Central America: evidence from a panel cointegration and error correction model. Energy Economics 31, 211-216.

Apergis, N., Payne, J.E., 2010a. Energy consumption and growth in South America: evidence from a panel error correction model. Energy Econ. 32, 1421-1426.

Apergis, N., Payne, J.E., 2010b. The emissions, energy consumption, and growth nexus: evidence from the commonwealth of independent states. Energy Policy 38, 650-655.

Arouri, M.H., Ben Youssef, A., M'henni, H., Rault, C., 2012. Energy consumption, economic growth and CO2 emissions in Middle East and North African countries. Energy Policy 45, 342-349.

Azomahou, T., Laisney, F., Van, P. N., 2006. Economic development and CO2 emissions: A nonparametric panel approach. Journal of Public Economics 90, 1347-1363.

Banerjee, A. and Carrion-i-Silvestre, J., 2006, Cointegration in Panel Data with Breaks and Cross-section Dependence", European Central Bank, Working Paper 591, February.

Banerjee, A., Massimiliano, M. and Osbat, C., 2005. Testing for PPP: should we use panel methods? Empirical Economics 30, 77-91.

Baranzini, A., Weber, S., Bareit, M., Mathys, N.A., 2013. The causal relationship between energy use and economic growth in Switzerland. Energy Economics 36, 446-470.

Bartleet, M., Gounder, R., 2010.Energy consumption and economic growth in New Zealand: Results of trivariate and multivariate models. Energy Policy 38, 3508-3517.

Belloumi, M., 2014. The relationship between trade, FDI and economic growth in Tunisia: An application of the autoregressive distributed lag model. Economic Systems 38, 269-287.

Chen, S.T., Kuo, H.I., Chen, C.C., 2007. The relationship between GDP and electricity consumption in 10 Asian Countries. Energy Policy 35, 2611-2621.

Dehesa, M., P. Druck, Plekhanov, A., 2007.. Relative Price Stability, Creditor Rights, and Financial Deepening. IMF Working Paper.

Ekins, P.,1997. The Kuznets curve for the environment and economic growth: examining the evidence. Environment and Planning A 29, 805-30.

Farhani, S., Muhammad, S., Sbia, R., Chaibi, A., 2014. What does MENA region initially need: Grow output or mitigate $\mathrm{CO}_{2}$ emissions? Economic Modelling 38, 270-281.

Fodha, M., Zaghdoud, O., 2010. Economic growth and environmental degradation in Tunisia: an empirical analysis of the Environmental Kuznets Curve. Energy Policy 38, 1150-1156.

Friedl, B., M. Getzner, M., 2003. Determinants of CO2 emissions in a small open economy. Ecological Economics 45, 133-148

Ghosh, S., 2010. Examining carbon emissions-economic growth nexus for India: a multivariate cointegration approach. Energy Policy 38, 2613-3130.

Grossman, G., Krueger, A., 1991. Environmental impacts of a North American free trade agreement. National Bureau of Economics Research Working Paper, No. 3194. NBER, Cambridge.

Halicioglu, F., 2009. An econometric study of $\mathrm{CO}_{2}$ emissions, energy consumption, income and foreign trade in Turkey. Energy Policy 37, 1156-1164.

Heil, M. T., Selden, T.M., 1999. Panel stationarity with structural breaks: carbon emissions and GDP. Applied Economics Letters 6, 223-225.

Hossain, M.S., 2011. Panel estimation for $\mathrm{CO}_{2}$ emissions, energy consumption, economic growth, trade openness and urbanization of newly industrialized countries. Energy Policy 39, 6991-6999.

Im, K.S., Pesaran, M.H., Shin, Y., 2003. Testing for unit roots in heterogeneous panels. Journal of Econometrics $115,53-74$.

Islam, F., Shahbaz, M., Alam, M., Ahmed, A. U., 2013. Financial development and energy consumption nexus in Malaysia: a multivariate time series analysis. Economic Modeling, 30, 435-441.

Jalil, A., Mahmud, S.F., 2009. Environment Kuznets curve for $\mathrm{CO}_{2}$ emissions: a cointegration analysis for China. Energy Policy 37, 5167-5172. 
Jalil, A., Feridun, M., 2011. The impact of growth, energy and financial development on the environment in China: A cointegration analysis. Energy Economics 33, 284-91.

Jaunky, V.C., 2010. The $\mathrm{CO}_{2}$ emissions-income nexus: evidence from rich countries. Energy Policy 39, 12281240.

Jayanthakumaran, K., Verma, R., Liu, Y., 2012. CO2 emissions, energy consumption, trade and income: a comparative analysis of China and India. Energy Policy 42,450-460.

Kohler, M., 2013. $\mathrm{CO}_{2}$ emissions, energy consumption, income and foreign trade: A South African perspective. Energy Policy 63, 1042-1050.

Lean, H.H., Smyth, R., 2010a. Multivariate Granger causality between electricity generation, exports and GDP in Malaysia. Energy Economics 35, 3640-3648.

Lean, H.H, Smyth, R., 2010b. CO2 emissions, electricity consumption and output in ASEAN. Applied Energy 87, 1858-1864.

Lee, W.J., 2013. The contribution of foreign direct investment to clean energy use, carbon emissions and economic growth. Energy Policy 55, 483-489.

Levin, A., Lin, C.F., Chu, C.S., 2002. Unit root tests in panel data: Asymptotic and finitesample properties. Journal of Econometrics 108, 1-24.

Lotfalipour, M.R., Falahi, M.A., Ashena, M., 2010. Economic growth, $\mathrm{CO}_{2}$ emissions, and fossil fuels consumption in Iran. Energy 35, 5115-5120.

Managi, S., Jena, P.R., 2008. Environmental productivity and Kuznets curve in India. Ecological Economics 65 , 432-440.

Managi, S., Hibiki, A. and Tsurumi, T., 2009, Does trade openness improve environmental quality? Journal of Environmental Economics and Management, 58, 346-363.

Menyah, K., Wolde-Rufael, Y., 2010. CO2 emissions, nuclear energy, renewable energy and economic growth in the US. Energy Policy 38, 2911-2915.

Menyah, K., Nazlioglu, S., Wolde-Rufael, Y. 2014. Financial development, trade openness and economic growth in African countries: New insights from a panel causality approach. Economic Modelling 37, 386-394.

Narayan, P.K., Smyth, R., 2009. Multivariate Granger causality between electricity consumption, exports and GDP: evidence from a panel of Middle Eastern countries. Energy Policy 37, 229-236.

Nasir, M., Rehman, F., 2011. Environmental Kuznets curve for carbon emissions in Pakistan: an empirical investigation. Energy Policy 39, 1857-1864.

Nasreen, S., Anwar, S., 2014. Causal relationship between trade openness, economic growth and energy consumption: A panel data analysis of Asian countries. Energy Policy 69, 82-91.

Newey, W.K., 1985. Generalized method of moments specification testing. Journal Econometrics.29,229-256.

Omri, A., 2013. $\mathrm{CO}_{2}$ emissions, energy consumption and economic growth nexus in MENA countries: evidence froms imultaneous equations models. EnergyEconomics 40, 657-664.

Omri, A., Nguyen, D.K., Rault, C., 2014. Causal Interactions between $\mathrm{CO}_{2}$ Emissions, Foreign Direct Investment, and Economic Growth: Evidence from Dynamic Simultaneous-Equation Models. Economic Modelling 42, 382-389.

Omri, A., 2014. An International Literature Survey on Energy-Economic Growth nexus: Evidence from Country-Specific Studies. Renewable \& Sustainable Energy Reviews 38, 951-959.

Ozturk, I., Acaravci, A., 2010. CO2 emissions, energy consumption and economic growth in Turkey. Renew. Sustain. Energy Rev. 14, 3220-3225.

Ozturk, I., Acaravci, A., 2013. The long-run and causal analysis of energy, growth, openness and financial development on carbon emissions in Turkey. Energy Economics 36, 262-267.

Pedroni, P., 1999. Critical Values for Cointegrating Tests in Heterogeneous Panels with Multiple Regressors, Oxford Bulletin of Economics and Statistics 61, 653-670.

Pedroni, P., 2004. Panel Cointegration; Asymptotic and Finite Sample Properties of Pooled Time Series Tests with an Application to the Purchasing Power Parity Hypothesis, Econometric Theory 20, 597-625.

Pereira, A.M., Pereira,R.M.M., 2010. Is fuel-switching a no-regrets environmental policy? VAR evidence on carbon dioxide emissions, energy consumption and economic performance in Portugal. Energy Economics $32,227-242$.

Pesaran, M., 2007, A Simple Panel Unit Root Test in the Presence of Cross Section Dependence, Journal of Applied Econometrics 22, 265-312.

Richmond, A.K., Kaufmann, R.K., 2006. Is there a turning point in the relationship between income and energy use and/or carbon emissions? Ecological Economics 56, 176-189.

Saboori, B., Sulaiman, J., Mohd, S., 2012. Economic growth and $\mathrm{CO}_{2}$ emissions in Malaysia: a cointegration analysis of the environmental Kuznets curve. Energy Policy 51, 184-191.

Sadorsky, P., 2010. The impact of financial development on energy consumption in emerging economies. Energy Policy 38, 2528-2535. 
Sadorsky, P., 2012. Energy consumption, output and trade in South America. Energy Economics 34, 476-488.

Selden, T. M., Song, D., 1994. Environmental quality and development: Is there a Kuznets curve for air pollution?' Journal of Environmental Economics and Management 27, 147-62.

Shafik, N., 1994. Economic development and environmental quality: an econometric analysis. Oxford Economic Papers 46, 757-73.

Shahbaz, M., Lean, H.H., 2012. Does financial development increase energy consumption? The role of industrialization and urbanization in Tunisia. Energy Policy 40, 473-479.

Shahbaz, M., Lean, H.H., Shabbir, M.S., 2012. Environmental Kuznets Curve hypothesis in Pakistan: cointegration and Granger causality. Renew. Sust. Energ. Rev. 16, 2947-2953.

Shahbaz, M., 2013. Does financial instability increase environmental degradation? Fresh evidence from Pakistan, Economic Modelling 33, 537-544.

Shahbaz, M., Lean, H.H., Farooq, A., 2013a. Natural gas consumption and economic growth in Pakistan. Renew. Sust. Energ. Rev. 18, 87-94.

Shahbaz, M., Hye, Q.M.A., Tiwari, A.K., Leitão, N.C., 2013b. Economic growth, energy consumption, financial development, international trade and CO2 emissions in Indonesia. Renew. Sust. Energ. Rev. 25, $109-121$.

Shahbaz, M., Mutascu, M., Azim, P., 2013c. Environmental Kuznets curve in Romania and the role of energy consumption. Renew. Sust. Energ. Rev. 18, 165-173.

Shahbaz, M., Khan, S., Tahir, M.I., 2013d. The dynamic links between energy consumption, economic growth, financial development and trade in China: Fresh evidence from multivariate framework analysis. Energy Economics 40, 8-21.

Shahbaz, M., Solarin, S. A., Mahmood, H. Arouri, M., 2013e. Does financial development reduce CO2 emissions in Malaysian economy? A time series analysis. Economic Modelling 35, 145-152.

Shahbaz, M., Tiwari, A. K., Nasir, M., 2013f. The effects of financial development, economic growth, coal consumption and trade openness on CO2 emissions in South Africa. Energy Policy, 61, 1452-1459.

Shahbaz, M., Khraief, N., Uddin, G. S., Ozturk, I., 2014a. Environmental Kuznets curve in an open economy: A bounds testing and causality analysis for Tunisia. Renewable and Sustainable Energy Reviews, 34, 325 336.

Shahbaz, M., Sabia, R., Hamdi, H., Ozturk, I., 2014b. Economic growth, electricity consumption, urbanization andenvironmental degradation relationship in United Arab Emirates. Ecological Indicators, 45, 622-631.

Sharma, S.S., 2010. The relationship between energy and economic growth: empirical evidence from 66 countries. Applied Energy 87, 3565-3574.

Sharma, S.S., 2011. Determinants of carbon dioxide emissions: empirical evidence from 69 countries. Applied Energy 88, 376-382.

Smith, R.J.,Blundell,R.W.,1986.An exogeneity test for a simultaneous equation tobit model with an application to labor supply. Econometrica54,679-685.

Soytas, U., Sari, R., Ewing, B.T., 2007. Energy consumption, income, and carbon emissions in the United States. Ecological Economics 62, 482-489.

Soytas, U., Sari, R., 2009. Energy consumption, economic growth, and carbon emissions: challenges faced by an EU candidate member. Ecological Economics 68, 2706-2712.

Stern, D.I., 1993. Energy growth in the USA: a multivariate approach. Energy Econ. 15,137-150.

Stern, D. I., Common, M.S., Barbier, E.B., 1996. Economic growth and environmental degradation: the environmental Kuznets curve and sustainable development. World Development 24, 1151-60.

Stern, D.I., 2000. A multivariate cointegration analysis of the role of energy in the US macroeconomy. Energy Economics 22, 267-283.

Tamazian, A., Piñeiro, J., Vadlamannati, K. C., 2009. Does higher economic and financial development lead to environmental degradation: evidence from BRIC countries? Energy Policy 37, 246-253.

Tamazian, A., BhaskaraRao, B., 2010. Do economic,financial and institutional developments matter for environmental degradation? Evidence from transitional economies. Energy Economics 32,137-145.

Tiwari, A.K., Shahbaz, M., Hye, Q.M.A., 2013. The environmental Kuznets Curve and the role of coal consumption in India: Co-integration and causality analysis in an open economy.Renewable and Sustainable Energy Reviews 18 , 519-527.

Wang, S.S., Zhou, D.Q., Zhou, P., Wang, Q.W., 2011. CO2 emissions, energy consumption and economic growth in China: A panel data analysis. Energy Policy 39, 4870-4875.

Wolde-Rufael, Y., 2005. Energy demand and Economic growth: the African experience. Journal of Policy Modeling 27, 891-903.

Yuan, J., Zhao, C., Yu, S., Hu, Z., 2007. Electricity consumption and economic growth in China: cointegration and co-feature analysis. Energy Economics 29, 1179-1191. 
Yücel, F., 2009. Causal Relationships Between Financial Development, Trade Openness and Economic Growth: The Case of Turkey. Journal of Social Sciences 5, 33-42.

Zhang, X.P., Cheng, X.M., 2009. Energy consumption, carbon emissions, and economic growth in China. Ecological Economics 68, 2706-2712.

Zhang,Y.J.,2011. The impact of financial development on carbon emissions: An empirical analysis in China. Energy Policy 39, 2197-2203.

Zhixin, Z., Xin, R., 2011. Causal Relationships between Energy Consumption and Economic Growth. Energy Procedia 5, 2065-2071.

Zoli, E.,2007. Financial Development in Emerging Europe: The Unfinished Agenda. IMF Working Paper. 